\title{
Analisis Perbandingan Keuntungan Usaha Pembenihan dan Pendederan Ikan Patin (Pangasius sp.) dengan Perolehan Bunga Deposito Bank
}

\author{
[Comparative Analysis of Benefits of Hatchery Business and Nursery Patin (Pangasius sp.) \\ with Acquisition of Bank Deposit Interest] \\ Iskandar Musa $\bowtie$ \\ Sekolah Tinggi Perikanan, Jurusan Penyuluhan Perikanan \\ Jalan Cikaret Nomor 1 Bogor 16001, Jawa Barat \\ Diterima: 8 Desember 2016; Disetujui: 15 Februari 2017
}

\begin{abstract}
Abstrak
Setiap kegiatan perekonomian mengharapkan efesiensi dan efektifitas dalam penggunaan faktorfaktor produksi. Kegiatan pembenihan ikan patin merupakan salah satu kegiatan produksi yang menggunakan sumber daya modal finansial. Modal merupakan faktor produksi yang harus dikelola secara efisien dan efektif dalam penggunaannya seperti faktor produksi lain berupa bahan atau barang, karena biaya akan terus dikeluarkan seiring dengan berjalannya waktu. Penggunaan faktor produksi harus tepat agar tidakterjadi pemborosan. Analisis data dari hasil uji/penelitian yang didasarkan pada variable-variable input dan output dapat diperoleh suatu perbandingan antara penyertaan modal pada usaha pembenihan ikan patin dengan penempatkan dana dalam bentuk deposito pada bank. Dari rencana penyertaan dan penempatan modal tersebut; 1) manakah yang lebih menguntungkan, investasi pada usaha pembenihan dan pendederan ikan patin (Pangasius sp.) ? atau 2) mendepositokan modal senilai investasi tersebut pada bank? Analisis ini menunjukkan Usaha pembenihan ikan patin dengan penggunaan dua ekor induk betina yang menghasilkan larva sebanyak 1.288.000 ekor per tahun dengan harga jual per ekor Rp $5,-$, tidak layak.Sedangkan sekuen pendederan, dari hasil analisis kelayakan usaha yang terdiri atas Laba/Rugi, R/C, BEP dan PP, menunjukkan nilai yang memenuhi syarat kelayakan. Kesimpulannya usaha ini bisa dipertimbangkan untuk dipilih sebagai alternatif investasi, karena perolehan keuntungannya melebihi perolehan bunga deposito bank.
\end{abstract}

Kata kunci: deposito, keuntungan, patin, pembenihan, pendederan, .

\begin{abstract}
Every economic activity expects efficiency and effectiveness in the use of factors of production. Catfish hatchery activity is one of the production activities that use financial capital resources. Capital is a production factor that must be managed efficiently and effectively in its use such as other production factors in the form of materials or goods, because the costs will continue to be issued over time. The use of production factors must be appropriate to avoid waste. Data analysis from test result based on input and output variables can be obtained a comparison between capital investment in catfish hatchery business by placing funds in the form of deposits at the bank. Of the planned investment and placement of such capital; 1) Which is more profitable, investment in hatchery and nursery catfish (Pangasius sp) or 2) depositing the investment's worth of capital in the bank? This analysis shows catfish breeding business with the use of 2 female mains that produce larvae as much as 1,288,000 larvae per year with selling price per larva $\mathrm{Rp} \mathrm{5,} \mathrm{-,} \mathrm{not}$ feasible.While nursery activities, from the results of business feasibility analysis consisting of Profit / Loss, R / C, BEP and PP, indicating the eligible value of eligibility. In conclusion this business can be considered to be chosen as an alternative investment, because the acquisition of profits exceeds the acquisition of interest on bank deposits.
\end{abstract}

Keywords: benefits, catfish,deposits, nursery,,seeding.

$\bar{\triangle}$ Penulis korespondensi
Alamat surel: iskandarmusa60@yahoo.com

Jurnal Penyuluhan Perikanan dan Kelautan 


\section{PENDAHULUAN}

Sebagai salah satu negara yang memiliki kekayaan hasil perikanan yang beraneka ragam, Indonesia berpeluang mendatangkan devisa negara yang cukup besar terutama dari hasil ekspornya ke negara-negara Uni Eropa, Amerika, Jepang, Thailand, dan negara-negara lainnya. Melimpahnya hasil perikanan ini dapat dimanfaatkan pula dalam rangka pemenuhan gizi bagi masyarakat Indonesia sendiri dengan mengkonsumsi hasil perikanannya atau dapat dijadikan berbagai produk diversifikasi pangan yang bernilai ekonomis tinggi.

Ikan-ikan air tawar memiliki nilai gizi serta nilai ekonomis yang tinggi, selain karena rasanya banyak disukai oleh penduduk Indonesia dan juga penduduk di negara-negara lain sehingga banyak dilakukan kegiatan ekspor untuk memenuhi permintaan pasarnya. Ikan air tawar memiliki nilai gizi yang tinggi seperti halnya ikan laut, mudah dalam pemeliharaan dan harganya relatif murah, selain itu permintaannya yang tinggi di pasar domestik maupun pasar internasional, yang dapat menyebabkan keberlanjutan usaha budidaya dapat berlangsung dalam jangka panjang.

Salah satu komoditi perikanan budidaya air tawar yang memiliki nilai ekonomis tinggi adalah ikan patin. Hal ini dibuktikan dengan meningkatnya permintaan pasar terhadap kebutuhan pemenuhan ikan ini ke sejumlah negara.Ikan Patin (Pangasius sp.) telah lama dibudidayakan di wilayah Indonesia, penyebarannya meliputi beberapa pulau, antara lain: Jawa, Sumatera, Kalimantan, Bali, dan Sulawesi.

Budidaya komoditas ikan patin juga menunjukkan kecenderungan yang meningkat, kondisi ini disebabkan adanya peningkatan permintaan pada ikan tingkat ukuran konsumsi, yang berimplikasi kepada suatupeningkatan permintaan benih baik kuantitas maupun kualitas. Produksi benih patin di daerah Bogor dan Sukabumi tidak hanya untuk memenuhi kebutuhan lokal, namun sebagian dikirim keluar pulau, antara lain ke pulau: Sumatera, Bali, Nusa Tenggara dan Kalimantan.

Untuk juga memproduksi benih patinukuran tertentu terdapat beberapa segmen kegiatan tersendiri yang meliputi usaha pada unit panti pembenihan dan pendederan. Kegiatan tersebut dilakukan oleh para pembudidaya pada suatu wadah berupa akuarium di panti benih. Kegiatan usaha pembenihan biasanya dilakukan pada unit-unit pembenihan rakyat (UPR) skala kelompok kecil atau 
keluarga, baik sebagai usaha pokok atau hanya sebagai usaha sampingan.

Melihat kenyataan bahwa kegiatan pembenihan dan pendederan ikan patin menjadi salah satu jenis usaha atau kegiatan usaha tersendiri, maka diperlukan kajian yang lebih rinci sertamendetail yang berkaitan dengan parameter-parameter analisis ekonomi pada kegiatan usaha tersebut.Salah satu tolok ukur keberhasilan suatu usaha adalah besarnya margin laba/keuntungan yang diperoleh. Perhitungan margin laba secara sederhana dapat dilakukan dengan mengetahui berapa besarnya penerimaan (revenue) dan besarnya biaya (cost) yang dikeluarkan pada suatu unit produksi.

Setiap unit kegiatan perekonomian tentu selalu mengharapkan efesiensi dan efektifitas dalam penggunaan faktorfaktor produksi. Kegiatan pembenihan ikan patin salah satu kegiatan produksi yang menggunakan sumber daya modal finansial. Sumberdaya terkait modal finansial merupakan faktor produksi yang harus dikelola secara efisien dan efektif dalam penggunaannya seperti faktor produksi lain yang berupa bahan atau barang, karena biaya akan terus dikeluarkan seiring dengan berjalannya waktu. Untuk itu penggunaanya harus tepat agar tidakterjadi pemborosan.
Dengan melakukan analisis data yang diambil dari hasil uji/penelitian yang didasarkan pada variable-variable input dan output maka akan dapat diperoleh suatu perbandingan antara penyertaan modal pada unit usaha pembenihan komoditas/jenis ikan patin dengan penempatkan dana dalam bentuk deposito pada suatu bank. Dari rencana penyertaan dan juga penempatan modal tersebut:(1) manakah yang akan lebih menguntungkan, investasi pada usaha pembenihan dan pendederan ikan patin (Pangasius sp.)? atau pada pilihan (2) mendepositokan modal senilai investasi tersebut pada bank?

Tujuan yang ingin dicapai dalam penelitian ini adalah:

1. Membandingkan mana yang lebih menguntungkan antara penyertaan modal pada usaha pembenihan dan pendederan ikan patin (Pangasius sp) atau perolehan bunga deposito bank;

2. Memberikan gambaran bagicalon investor dalam upaya pengambilan keputusan peggunaan dana antara investasi pada usaha pembenihan dan pendederan ikan patin atau deposito.

\section{Teknologi dalam pembenihan patin}

Pemijahan buatan perlu dilakukan karena ikan patin (siam, djambal, dan 
pasopati) dalam wadah budidaya sangat sulit melakukan pemijahan secara alami. Pemijahan buatan dilakukan dengan dua metode yaitu sistem kering dan sistem basah.

Dalam sistem kering ini telur yang telah dikeluarkan dan ditampung dalam wadah, kemudian dicampur dengan sperma yang baru/langsung dikeluarkan dari induk jantan, lalu dicampur dengan menggunakan alat pengaduk dari bulu ayam selama kurang lebih satu menit. Kemudian untuk aktifasi ditambahkan air yang kaya oksigen sambil diaduk-aduk. Selanjutnya dibilas dengan air segar beberapa kali, kemudian ditetaskan.

Pada sistem basah ini, sebelum telur dikeluarkan, terlebih dahulu sperma dari induk jantan diencerkan dengan larutan $\mathrm{NaCl}$ (Natrium Khlorida) fisiologis. Larutan tersebut selain berfungsi sebagai pengencer juga berfungsi sebagai pengawet. Spermatozoa dapat tahan hidup dalam larutan tersebut selama 12-24 jam pada suhu $5-10^{\circ} \mathrm{C}$.

Prosedur pemijahan secara buatan dapat dilakukan sebagai berikut: (1) Sediakan wadah penampung telur; (2) Siapkan sperma induk jantan dalam larutan $\mathrm{NaCl}$; (3) Perut induk betina diurut secara perlahan, lalu telur di tampung dalam wadah; (4) Masukan sperma dan lakukan pengadukan dengan menggunakan bulu ayam, dan

Tebarkan telur ke dalam akuarium.

Penetasan telur dilakukan dalam akuarium yang diisi air bersih setinggi 25-30 cm dan dipasang aerasi sebagai pensuplai oksigen. Umumnya telur ikan patin menetas pada suhu tinggi, antara 28-30 ${ }^{\circ} \mathrm{C}$, setelah 18-28 jam kedepan. Kondisi suhu juga dapat dipertahankan dengan menggunakan alat pemanas. Setelah telur menetas, larva dipindah ke akuarium dan diberi pakan Artemia serta cacing sutra; juga dilakukan pergantian air. Tahap berikut adalah pendederan, kemudian tahap terakhir adalah pembesaran (Lampiran 1) .

Pengertian modal usaha adalah uang yang dipakai sebagai pokok (induk) untuk berdagang, melepas uang, dan sebagainya; harta benda (uang, barang, dan lain sebagainya) yang dapat juga dipergunakan untuk menghasilkan sesuatu yang menambah profit. Modal dalam pengertian ini dapat diartikan sebagai sejumlah uang yang digunakan dalam menjalankan kegiatan (Listyawan, 2011). Banyak dari kalangan yang memandang bahwauang bukanlah segala-galanya dalam sebuah bisnis. Namun perlu dipahami bahwa uang dalam sebuah usaha sangat diperlukan. 
Modal dapat digunakan untuk menjalankan suatu usaha atau segala nilai sesuatu aktiva yang dimiliki oleh perusahaan dan yang digunakan untuk mengahasilkan pendapatan. Modal dapat berasal dari dalam perusahan atau dari luar perusahaan. Dalam finansial dan akunting modal biasanya menunjuk kepada kekayaan finansial terutama dalam penggunaan awal atau menjaga kelanjutan bisnis.

Pengertian deposito menurut Simorangkir (1985) adalah bahwa: Deposito adalah setiap jumlah uang yang dapat disetor oleh seseorang debitur atau penyewa sebagai uang panjar atau uang muka, baik telah dikredit maupun akan dikredit kepadanya atas nama deposito atau uang muka, baik jumlah tersebut akan telah dibayar kepada kreditur atau pemilik atau seseorang lainnya, atau akan telah dilunaskan melalui pembayaran uang atau transfer atau melalui penyerahan barang-barang atau dengan cara lain.

Menurut Undang-Undang Nomor 10/1998, Pasal 1 ayat 7 (1998) yang memberikan pengertian deposito adalah sebagai berikut: Deposito adalah simpanan yang penarikannya hanya dapat dilakukan pada waktu tertentu berdasarkan perjanjian dengan nasabah penyimpan melalui bank. Sedangkan menurut Suyatno (1989), pengertian deposito adalah: Simpanan pihak ketiga pada bank yang penarikannya hanya dapat dilakukan dalam waktu tertentu menurut perjanjian pihak ketiga dengan bank yang bersangkutan.

Pada umumnya deposito dapat digolongkan menurut jangka waktu. Beberapa penggolongan deposito tersebut adalah sebagai berikut:

\section{A. Demand deposit (Rekening Koran)}

Demand deposit (rekening koran) pada bank-bank di Amerika Serikat dapat digolongkan menjadi: (1) Inter bank deposit (deposito-deposito antar bank) yaitu deposito yang disimpan, baik dengan bank yang mendepositokan maupun bagi yang menerimanya; (2) Deposito-deposito pemerintah Amerika Serikat bagi bank-bank dagang disebut oleh bank-bank sebagai rekeningrekening pajak dan pemberian pinjaman (Tax and loan atau Tax \& accounts), karena timbul proses-proses perpajakan dan pemberian pinjaman; (3) Deposito negara bagian dan daerah, merupakan deposito-deposito berbagai macam pembagian unsur politik termasuk distrik-distrik, sekolah dan sebagainya; (4) Deposito-deposito pemerintahan yang disimpan oleh para individu firmafirma dan perusahaan-perusahaan yang berbentuk badan hukum. 


\section{B. Time deposits}

Tidak seperti deposito-deposito rekening koran yang pada umumnya homogen macamnya, deposito berjangka dan deposito tabungan ditawarkan dalam aneka ragam bentuk. Namun demikian, ciri-ciri yang umum dan sama dari deposito-deposito tersebut adalah juga kewajiban bank membayar tingkat bunga karena nasabah memerlukan jangka waktu tertentu sebelum depositodeposito tersebut dicairkan kembali.

Ada tiga macam bentuk dasar dari deposito berjangka dan atau deposito tabungan, yaitu :

\section{(1) Deposito tabungan dan buku kas}

Merupakan jenis deposito yang paling dikenal diantara berbagai macam rekening simpanan dan tidak ada jatuh waktu khusus untuk deposito tersebut, serta dalam prakteknya dana-dana yang didepositokan dalam rekening-rekening tersebut dapat ditambahkan dan ditarik kembali pada waktu yang sesuai bagi depositonya. Deposito dari tabungan kekhasnya, yakni membayar tingkat bunga yang lebih rendah daripada deposito-deposito berjangka.

\section{(2) Sertifikat deposito berjangka}

Merupakan bukti bahwa seseorang atau sebuah perusahaan yang berbentuk badan hukum telah mendepositokan sejumlah uang tertentu di sebuah bank.
Ciri-ciri yang mendasar dari rekening deposito ini adalah bahwa dana yang didepositokan tidak dapat ditarik kembali oleh pemiliknya paling sedikit selama 30 hari (atau lebih) dan bahwa sertifikat-sertifikat dijual oleh bank dalam denominasi-denominasi tetap, misalnya $\$ 1000, \$ 5000$ dan $\$ 100.000$.

Dilain pihak ada pula yang mendefinisikan sertifikat deposito sebagai simpanan berjangka atas pembawa atau unjuk dengan izin otoritas moneter dan dikeluarkan oleh bank sebagai bukti simpanan yang dapat diperjualbelikan atau dipindah tangankan kepada pihak ketiga. Dalam kaitan ini bunga dibayar dimuka dalam arti dipotong dari nominalnya pada waktu sertifikat deposito itu dibeli. Misalnya sertifikat deposito berjangka nominal Rp.1.000.000 dibeli tunai dengan Rp.940.000, setelah sertifikat jatuh tempo akan diterima kembali uang sebesar Rp.1.000.000. Sertifikat deposito dapat diperjual belikan dalam 1 bulan, 3 bulan, 6 bulan, 12 bulan. Bunga yang diberikan bank yang menerbitkan sertifikat berbeda satu dengan lainnya. Perbedaan ini tergantung dari kemampuan dan kebutuhan bank bersangkutan atas dana yang diinginkan untuk ditarik dari masyarakat, menjadi kedaluarsa dalam 30 tahun. 


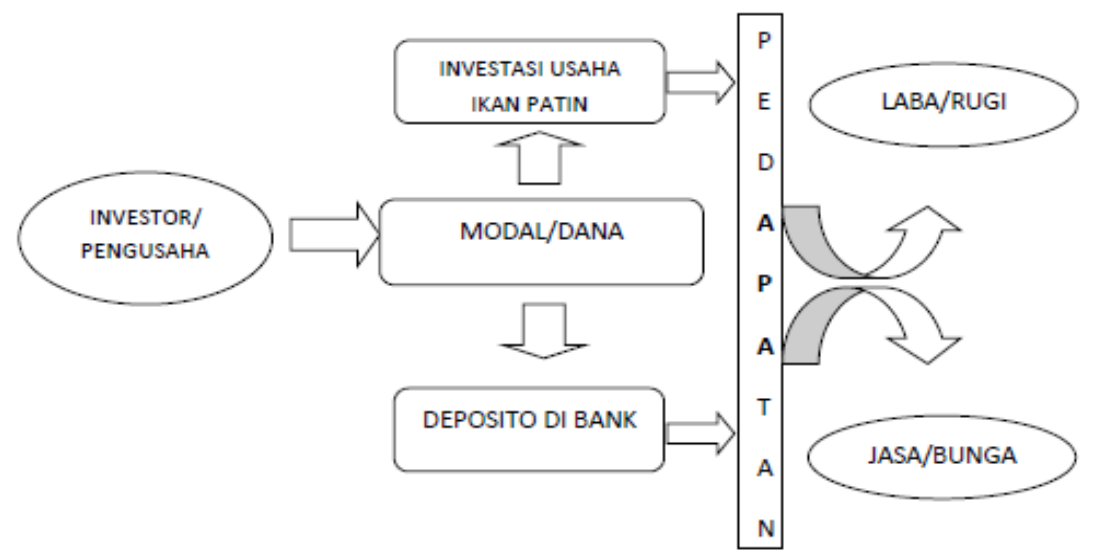

Gambar 1. Kerangka pemikiran perbandingan investasi usaha patin dan deposito bank

Dari penjelasan tentang sertifikat deposito tersebut di atas dapat dikemukakan beberapa hal sebagai berikut: (a) Sertifikat deposito bank adalah bukti penerimaan sejumlah uang yang dikeluarkan oleh bank; (b) Terikat pada suatu jangka waktu tertentu; (c) Diberikan imbalan yang biasanya dibayar dimuka pada saat membeli sertifikat deposito. (d) Bank yang mengeluarkan sertifikat deposito mempertanggungjawabkan seluruh harta kekayaannya; (e) Dikeluarkan atas unjuk; (f) Dapat diperjualbelikan atau dipindahtangankan hanya dengan cara penyerahan; (g) Pengeluaran sertifikat deposito sesuai dengan Undang-undang yang berlaku di negara-negara yang bersangkutan; (h) Bebas pajak atas bunga, deviden dan royalty; (i) Dapat dijadikan jaminan atas kredit. Selain itu dikenal pula istilah sertifikat deposito yang dirundingkan dan sertifikat deposito yang tak dirundingkan.

Perbedaan mendasar antara keduanya adalah bahwa sertifikat deposito yang dapat dirundingkan dapat dijual sebelum jatuh temponya oleh pembeli deposito asli, sedangkan pada sertifikat deposito yang tidak dapat dirundingkan, hanya pembeli asli yang merupakan orang yang dapat menguangkannya.

\section{(3) Deposito berjangka dengan rekening terbuka.}

Kata terbuka ini dalam istilah rekening terbuka berarti para deposan dapat mengembangkan jumlah barang pada deposito-deposito sesuka hatinya. Dalam arti bahwa jumlah uang tidak ditentukan oleh suatu Bank. Namun pengembangannya sesuai dengan prinsip deposito, tidak bisa ditarik sebelum waktunya. Deposito berjangka ini juga 
dikeluarkan atas nama. Seperti yang telah dikemukakan di atas bahwa deposito berjangka ini dikeluarkan dalam berbagai macam oleh bank. Beberapa jenis lain diantaranya adalah:

\section{Deposit on Call}

Deposito ini berupa simpanan yang berada dalam bank selama deposan membutuhkannya, dan berbeda dengan deposito berjangka lainnya apabila seorang ingin menarik simpanannya terlebih dahulu seseorang itu harus memberitahukan kepada bank, sesuai dengan perjanjian antara deposan dengan bank. Di luar negeri deposit on call ini banyak disukai oleh para nasabah.

\section{Deposit Automatic Roll-Over.}

Jika deposito yang telah jatuh tempo, tetapi pinjaman pokok belum diuangkan berarti uang deposan menganggur tanpa uang bunga, tetapi tidak demikian halnya dengan deposit automatic roll over secara otomatis diperhitungkan dengan bunganya demikian juga dengan deposito yanghabis waktunya dan deposan tertunda menarik uang depositonya yang sudah jatuh tempo.Gambar diatas dapat dijelaskan sebagai berikut: Investor atau pengusaha yang memiliki modal atau dana dapat melakukan investasi dalam bentuk usaha budidaya ikan patin (pembenihan atau pendederan) dengan memperhatikan faktor-faktor produksi. Kegiatan ini memiliki konsekuensi laba atau rugi. Selain itu investor atau pengusaha dapat juga melakukan penyimpanan dananya di bank dalam bentuk deposito. Secara konsepsi, deposito lebih aman. Namun perolehan pendapatannya terbatas karena hanya mengandalkan suku bunga yang ditentukan oleh pihak bank.

Sedangkan usaha budidaya ikan patin (pembenihan atau pendederan) memiliki peluang lebih besar dalam hal memperoleh keuntungan yang bila pengelolaan produksinya bisa maksimal dan kondisi pasarnya baik. Karena kedua bentuk penyertaan modal ini memiliki resiko, maka berdasarkan kerangka pikir di atas akan coba dibuktikan melalui penelitian dengan judul; Analisis Perbandingan Keuntungan Usaha Pembenihan dan Pendederan Ikan Patin (Pangasius sp.) dengan Perolehan Bunga Deposito Bank.

\section{BAHAN DAN METODE}

Penelitian ini didisain berbentuk survei dengan tujuan memperoleh data dari para pelaku utama dan pelaku usaha pembenihan ikan patin di kecamatan Ciseeng, kabupaten Bogor. Instrumen yang digunakan adalah kuisioner dalam bentuk blanko isian data skala usaha, 
modal investasi, biaya operasional, pendapatan dan pembukuan usaha. Disamping itu juga digunakan instrumen pengamatan yang disusun berdasarkan kebutuhan penelitian untuk melihat kondisi pelaku usaha di lapangan. Teknik pengambilan sampel pada penelitian survey ini yaitu dengan menggunakan metode pengambilan secara probability sampling yaitu secara simpel random sampling. Jumlah responden yang akan digunakan dalam penelitian sebanyak lebih kurang 10 sampai 15 responden.

Analisis usaha perikanan dapat dilakukan dengan menggunakan beberapa metode. Tujuan analisis usaha adalah untuk mengetahui tingkat keuntungan, pengembalian investasi, titik impas dan parameter kelayakan lainnya

\section{Analisis Laba/Rugi}

Analisis laba/rugi bertujuan untuk mengetahui besarnya keuntungan atau kerugian dari suatu usaha yang dikelola. Suatu usaha dikatakan untung bila nilai penerimaan (revenue) lebih besar dari total pengeluaran atau biaya (cost)

\section{Revenue Cost Ratio $(R / C)$}

Analisis R/C merupakan alat analisis untuk mengetahui keuntungan relatif suatu usaha dalam satu tahun terhadap biaya yang dipakai dalam kegiatan tersebut. Suatu usaha dikatakan layak bila R/C lebih besar dari 1 (R/C > 1). Semakin tinggi nilai $\mathrm{R} / \mathrm{C}$ maka tingkat keuntungan suatu usaha akan semakin tinggi. Sebaliknya bila R/C lebih kecil dari $1(\mathrm{R} / \mathrm{C}<1)$, maka usaha itu dikatakan tidak layak, karena tidak menguntungkan. $\mathrm{R} / \mathrm{C}=$ Total Penerimaan dibagi denganTotal Biaya

Payback Period (PP)

Payback period adalah suatu cara analisis untuk mengetahui waktu tingkat pengembalian investasi yang telah ditanamkan pada suatu jenis usaha. Secara umum, rumus yang digunakan adalah: $\mathrm{PP}=$ Total Investasi : Keuntungan x 1 tahun

\section{Break Even Point ( BEP)}

Analisis BEP merupakan alat analisis untuk mengetahui batas nilai produksi atau volume produksi suatu usaha mencapai titik impas (tidak untung dan tidak rugi). Usaha dinyatakan layak bila nilai BEP produksi lebih besar dari jumlah unit yang sedang diproduksi saat ini. Untuk menghitung BEP dapat menggunakan rumus sebagai berikut :

$\mathrm{BEP}($ unit $)=\mathrm{FC}: \mathrm{P}-\mathrm{VC}$

$\mathrm{BEP}($ rupiah $)=\mathrm{FC}: 1-\mathrm{VC} / \mathrm{P}$

Atau

BEP produksi =Total biaya : Harga penjualan 
BEP harga = Total biaya : Total produksi

dimana :

$\mathrm{FC}=$ Fixed $\operatorname{Cost}($ Biaya tetap $)$

$\mathrm{VC}=$ Variable Cost (Biaya tidak tetap)

$\mathrm{P}=$ Price $($ Harga $)$

Kegiatan penelitian dilaksanakan di Kecamatan Ciseeng, Kabupaten Bogor, dari bulan November sampai dengan bulan Desember 2015 Penentuan penelitian dilakukan secara sengaja (Purposive) yaitu lokasi yang dianggap cukup strategis untuk kegiatan agrobisnis perikanan.

\section{Analisa Usaha}

Analisis usaha pembenihan dilakukan pada unit usaha yang dipilih berdasarkan kriteria usaha yang mendekati standar usaha pembenihan dan pendederan ikan patin sesuai dengan standar yang direkomendasi oleh Kementrian Kelautan dan Perikanan (KKP).

\section{Komponen dan Struktur Biaya}

Komponen biaya dalam analisis kelayakan usaha pembenihan ikan patin dibedakan menjadi dua, yaitu biaya investasi dan biaya operasional. Biaya investasi adalah komponen biaya yang diperlukan untuk memenuhi kebutuhan dana awal pendirian usaha yang meliputi lahan/areal usaha, pembuatan kolam induk dan kolam pendederan, panti benih, peralatan dan sarana produksi. Sedangkan biaya operasional adalah seluruh biaya yang harus dikeluarkan dalam proses produksi.

\section{Biaya Investasi}

Untuk memulai usaha pembenihan ikan patin ini, dibutuhkan biaya investasi dengan komponen terbesar adalah pembelian lahan usaha dan bangunan panti benih ikan patin.Secara rinci, investasi pembenihan ikan patin ini disajikan dalam Tabel 1.

\section{Biaya Operasional}

Secara umum,biaya operasional dalam usaha pembenihan ikan patin dibedakan menjadi dua, yaitu biaya tetap dan biaya variabel. Total biaya tetap sebesar Rp 48.000.000 pertahun, sedangkan biaya variable sebesar Rp. 40.416.000,- pertahun, total biaya operasional adalah Rp.88.416.000,pertahun, dengan asumsi bahwa pada tahun pertama hingga tahun keempat usaha ini sudah dapat beroperasi dengan kapasitas 100\% (Tabel 2)

\section{HASIL DAN PEMBAHASAN}

Produksi dan Pendapatan Produksi telur dari dua induk ikan patin rata-rata minimal 230.000 butir untuk satu kali pemijahan. Dengan hatching rate sekitar161.000 ekor atau sekitar 70\%, 
Tabel 1. Rata-rata komposisi biaya investasi

\begin{tabular}{|c|c|c|c|c|c|}
\hline No & Komponen Biaya & Satuan & $\underset{\text { Fisik }}{\text { Jumlah }}$ & $\begin{array}{l}\text { Harga } \\
\text { per Satuan } \\
\text { (Rp) }\end{array}$ & $\begin{array}{c}\text { Jumlah } \\
\text { Biaya (Rp) }\end{array}$ \\
\hline 1 & Lahan & $\mathrm{m}^{2}$ & 800 & 40.000 & 32.000 .000 \\
\hline 2 & Perizinan dan Sertifikasi & & & & 1.500 .000 \\
\hline 3 & $\begin{array}{l}\text { Pembuatan kolam induk } \\
\text { (pematang tanah); } 10 \mathrm{x} \\
10 \times 1,2 \mathrm{~m} \text { (panjang } \mathrm{x} \\
\text { lebar } \mathrm{x} \text { tinggi) }\end{array}$ & Unit & 3 & 4.000 .000 & 12.000 .000 \\
\hline 4 & $\begin{array}{l}\text { Pembuatan kolam } \\
\text { pendederan (pematang } \\
\text { tanah); } 12 \times 10 \times 0,8 \mathrm{~m}\end{array}$ & Unit & 2 & 3.000 .000 & 6.000 .000 \\
\hline 5 & $\begin{array}{l}\text { Hapa/Wadah pemberokan } \\
\text { induk; } 3 \times 2 \mathrm{~m}\end{array}$ & Unit & 2 & 100.000 & 200.000 \\
\hline 6 & Panti benih ( $120 \mathrm{~m} 2)$ & Unit & 1 & 45.000 .000 & 45.000 .000 \\
\hline 7 & Bak/kolam treatmentair & Unit & 3 & 2.000 .000 & 6.000 .000 \\
\hline 8 & Bak pembenihan & Unit & 10 & 1.500 .000 & 15.000 .000 \\
\hline 9 & Wadah pakan alami & & & & 225.000 \\
\hline 10 & Pompa air & Unit & & & 4.000 .000 \\
\hline 11 & Sumurbor & Unit & 1 & 2.500 .000 & 2.500 .000 \\
\hline 12 & Sistem perpipaan air & Unit & 1 & 4.000 .000 & 4.000 .000 \\
\hline 13 & Sistem Aerasi & Unit & & & 4.800 .000 \\
\hline 14 & Alat tangkap & Unit & & & 1.085 .000 \\
\hline 15 & $\begin{array}{l}\text { Alat pemijahan } \\
\text { dan penetasan }\end{array}$ & Unit & & & 650.000 \\
\hline 16 & Alatdan sistem penunjang & Unit & & & 5.250 .000 \\
\hline \multirow[t]{2}{*}{17} & Induk dan calon induk & Unit & & & 6.800 .000 \\
\hline & Jumlah & & & & 147.010 .000 \\
\hline
\end{tabular}

Sumber : Lapangan dan adopsi PPUK BI.

Dengan harga larva per-ekor Rp 5, maka pendapatan yang diperoleh adalah sebesar Rp 805.000,- per-siklus atau sekitar Rp 6.440.000,- per-tahun untuk usaha pembenihan. Sedangkan untuk usaha pendederan dengan harga jual benih ukuran1 - 2 inchi sebesar Rp.170 per-ekor, pendapatan yang diperoleh adalah sebesar Rp18.700.000,- per-siklus atau sekitar Rp149.600.000,- per-tahun. akan menghasilkan larva. Dengan delapan siklus produksi per-tahun, usaha ini dapat memproduksi sebanyak 1.288.000 ekor larva.

\section{PerhitunganLabaRugi}

Perhitungan laba rugi bertujuan untuk mengetahui besarnya keuntungan atau kerugian dari suatu usaha yang dikelola. 
Analisis Perbandingan Keuntungan Usaha Pembenihan dan Pendederan Ikan Patin (Pangasius sp.) dengan Perolehan Bunga Deposito Bank

Tabel 2. Rata-rata komposisi biaya operasional

\begin{tabular}{|c|c|c|c|c|c|c|}
\hline No & Struktur biaya & Satuan & $\begin{array}{l}\text { Jumlah } \\
\text { Fisik }\end{array}$ & $\begin{array}{c}\text { Biaya } \\
\text { per } \\
\text { satuan } \\
\text { (Rp) }\end{array}$ & $\begin{array}{c}\text { Jumlah } \\
\text { biaya/bln } \\
\text { (Rp) }\end{array}$ & $\begin{array}{c}\text { Jumlah } \\
\text { biaya/thn } \\
\text { (Rp) }\end{array}$ \\
\hline
\end{tabular}

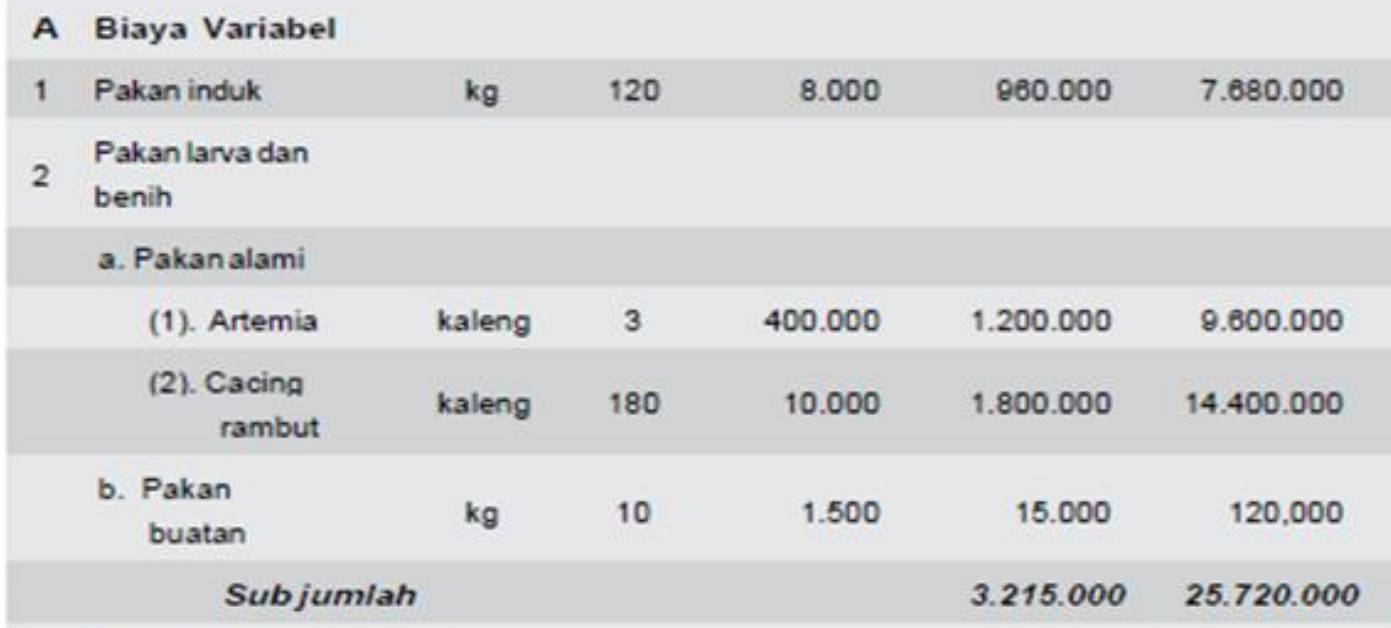

3 Pemijahan Induk

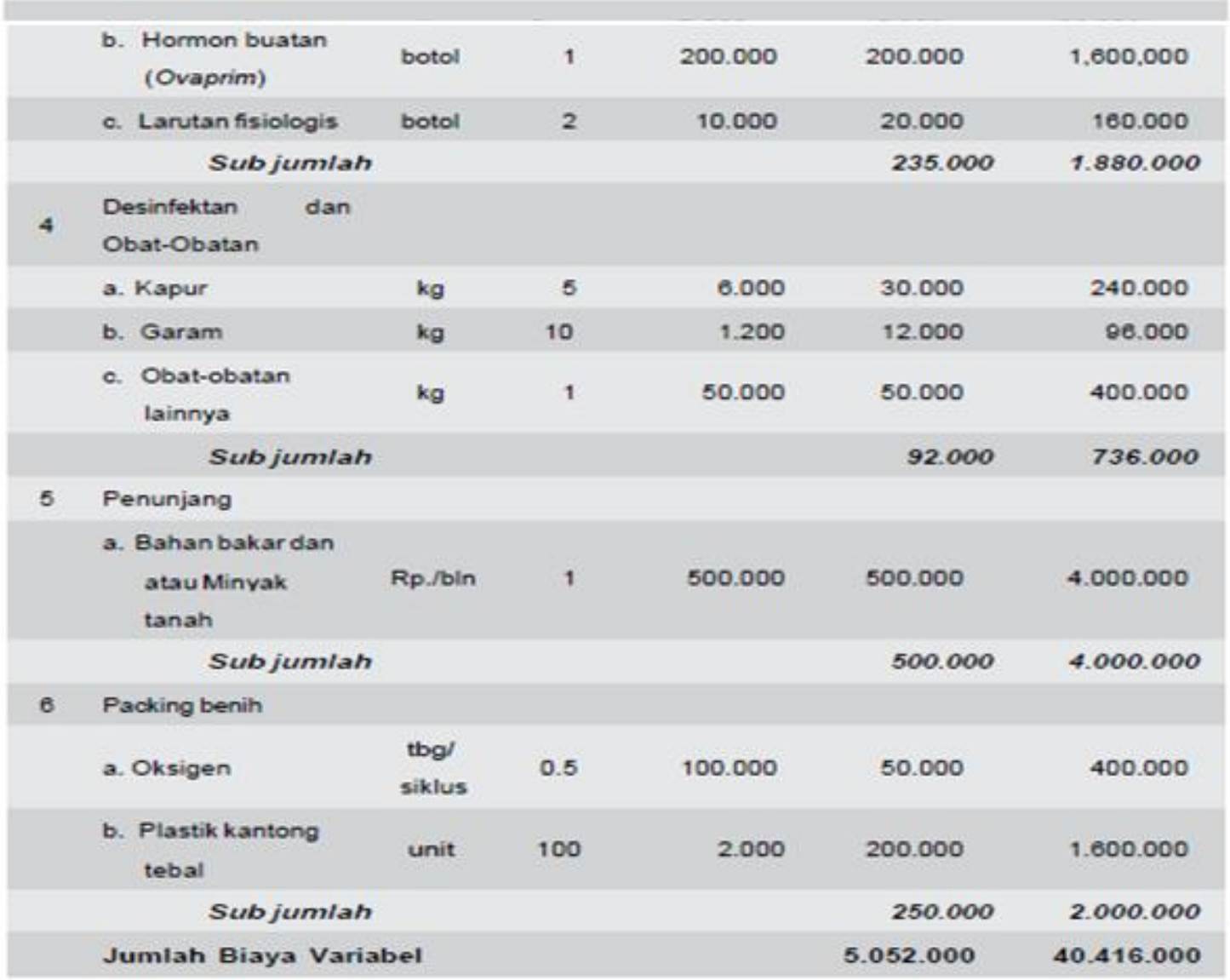


Sambungan Tabel 2.

\begin{tabular}{|c|c|c|c|c|c|c|}
\hline No & Struktur biaya & Satuan & Jumlah Fisik & $\begin{array}{c}\text { Biaya per } \\
\text { satuan } \\
\text { (Rp) }\end{array}$ & $\begin{array}{c}\text { Jumlah } \\
\text { biaya/bln } \\
\text { (Rp) }\end{array}$ & $\begin{array}{c}\text { Jumlah } \\
\text { biaya/thn } \\
\text { (Rp) }\end{array}$ \\
\hline B & Biaya Tetap & & & & & \\
\hline 1 & Listrik & Rp./bln & 1 & 250,000 & 250.000 & 2.000 .000 \\
\hline 2 & $\begin{array}{l}\text { Perawatan sarana } \\
\text { dan fasilitas }\end{array}$ & $\mathrm{Rp} / \mathrm{bln}$ & 1 & 500,000 & 500.000 & 4.000 .000 \\
\hline 3 & Tenaga kerja & & 3 & 1.750 .000 & 5.250 .000 & 42.000 .000 \\
\hline 4 & $\begin{array}{l}\text { Penyusutan } \\
\text { (10\% dari investasi) }\end{array}$ & & & & & 14.701 .000 \\
\hline $\begin{array}{l}\text { Jumlah } \\
\text { Biava Tetar }\end{array}$ & & & & & & 62.701 .000 \\
\hline Jumlah & Biaya Operasional & & & & & 103.117 .000 \\
\hline
\end{tabular}

Suatu usaha dikatakan untung bila nilai penerimaan (revenue) lebih besar dari total pengeluaran atau biaya (cost). Hasil perhitunganlabarugimenunjukkanbahwa usahapembenihan dan pendederan ikan patin mengalami kerugian per tahun sebesar Rp 48.806.500,- untuk usaha pembenihan. Sedangkan untuk usaha pendederan menghasilkan keunungan sebesar Rp 98.993.500,-

Revenue Cost Ratio (R/C)

$\mathrm{R} / \mathrm{C}$ adalah analisa untuk mengetahui keuntungan relatif pada usaha pembenihan dan pendederan ikan patin dalam satu tahun terhadap biaya yang dipakai dalam kegiatan tersebut

Tabel 4. Laba dan Rugi Usaha Pembenihan Ikan Patin

\begin{tabular}{|c|c|c|c|c|}
\hline No & Usaha & $\begin{array}{c}\text { Komponen/Pendapatan } \\
\text { per tahun (Rp) }\end{array}$ & Total Biaya (Rp) & $\begin{array}{c}\text { Laba/Rugi per } \\
\text { Tahun (Rp) }\end{array}$ \\
\hline 1 & Pembenihan & 6.440 .000 & 55.246 .500 & 48.806 .500 \\
\hline 2 & Pendederan & 149.600 .000 & 50.606 .500 & 98.993 .500 \\
\hline
\end{tabular}


Untuk unit usaha pembenihan, diperoleh nilai $\mathrm{R} / \mathrm{C}$ sebesar 0,12 atau lebih kecil dari 1, artinya usaha ini pada posisi penggunaan 2 ekor induk betina tidak layak. Sedangkan pada untuk pendederan, nilai $\mathrm{R} / \mathrm{C}$ nya 2,95 , artinya unit usaha pendederan layak untuk dilaksanakan.

\section{Break Even Point (BEP)}

BEP adalah analisa untuk mengetahui batas nilai produksi atau volume produksi usaha pembenihan dan pendederan ikan patin pada posisi tidak untung tidak rugi (impas). Berdasarkan hasil perhitungan, untuk usaha pembenihan, diperoleh nilai BEP produksi 11.049.300 ekor dan BEP harga Rp 42,89. Artinya usaha pembenihan akan mencapai titik impas bila produksinya (larva) mencapai 11.049.300 ekor larva dan harga jual $\mathrm{Rp}$ 42,89 per ekor. Dari hasil analisis BEP produksi dan harga, usaha pembenihan dinyatakan tidak layak, karena pada sekuen pembenihan jumlah produksi yang dicapai hanya 1.288 .000 ekor. Demikian pula dengan harga jual hanya Rp 5,- per ekor.Hasil analisis BEP untuk sekuen pendederan baik produksi maupun harga pada skala ini, dinyatakan layak dengan nilai kedua BEP tersebut diatas.
Payback Period (PP)

Payback period adalah analisa untuk mengetahui waktu tingkat pengembalian investasi yang telah ditanamkan pada usaha pembenihan dan pendederan ikan patin. Tingkat pengembalian investasi pada sekuen pembenihan, dinyatakan tidak layak karena usaha ini mengalami kerugian. Sedangkan untuk sekuen pendederan, berdasarkan hasil analisis seperti pada tabel 7, investasinya akan kembali selama 0,8 tahun atau 9,6 bulan. Artinya dalam 6 siklus produksi, nilai investasi sudah bisa kembali.

\section{SIMPULAN DAN SARAN}

\section{Simpulan}

Berdasarkan hasil dan pembahasan penelitian dengan judul: Analisis perbandingan keuntungan usaha pembenihan dan pendederan ikan patin (Pangasius sp.) dengan Perolehan Bunga Deposito Bank adalah sebagai berikut:

1. Usaha pembenihan ikan patin dengan penggunaan dua ekor induk betina yang menghasilkan larva sebanyak 1.288.000 ekor per tahun dengan harga jual per ekor Rp 5,-, tidak layak untuk dilaksanakan, karena semua parameter kelayakan usaha Laba/Rugi, R/C, BEP dan PP, setelah dianalisis menunjukan 
nilai yang tidak memenuhi syarat kelayakan.

2. Modal usaha untuk sekuen pembenihan sebesar Rp 197.056.500,- lebih baik digunakan untuk deposito pada bank, karena dengan bunga rata-rata perolehan bunga deposito berjangka pada bank pemerintah dan swasta saat ini sebesar 7,09\% per tahun atau 0,59 $\%$ per bulan. maka setiap tahun akan memperoleh Rp 13.971.305,atau sebesar Rp 1.164.275,- per bulan.

3. Untuk sekuen pendederan, dari hasil analisis kelayakan usaha yang terdiri atas Laba/Rugi, R/C, BEP dan PP, menunjukan nilai yang memenuhi syarat kelayakan. Dengan demikian usaha ini bisa dipertim bangkan untuk dipilih sebagai alternatif investasi, karena perolehan keuntungannya melebihi perolehan bunga deposito bank.

4. Sekuen pendederan patin ukuran $1-$ 2 inci dari penggunaan 2 ekor induk betina, dapat menghasilkan keuntungan sebesar Rp 98.993.500,per tahun, dibanding bila dideposito hanya akan menghasilakan sebesar Rp 9.212.852,- atau 9,3\%.

\section{Saran}

1. Penelitian tentang mana yang lebih menguntungkan antara penyertaan modal pada Usaha Pembenihan dan Pendederan Ikan Patin (Pangasius sp.) atau perolehan bunga deposito bank perlu mempertimbangkan faktor resiko dimana dalam penelitian ini hal tersebut belum dilakukan.

2. Investasi pada usaha pembenihan patin sebaiknya dilanjutkan dengan sekuaen pendederan sampai ukuran benih minimal $1-2$ inci.

\section{DAFTAR PUSTAKA}

Effendi I dan Oktariza W. 2006. Manajemen agribisnis perikanan. Jakarta

Husnan S. 1997. Manajemen Keuangan teori dan Penerapan (Keputusan jangka panjang). Yogyakarta (ID): BPFE

Hanafiah dan Saefudin. 2006. Tataniaga Hasil Perikanan. Jakarta (ID) Universitas Indonesia

Kadariah, L Kahlien dan G Clive. 1999. Pengantar Evaluasi Proyek. Jakarta (ID): FE UI

Kotler P, Amstrong G. 2008. Prinsipprinsip Pemasaran [Jilid 1 Edisi 12 Terjemahan]. Jakarta (ID): Erlangga

Mahyuddin K. 2010. Panduan Lengkap Agribisnis Patin. Jakarta (ID): Penebar Swadaya

Nasrudin W dan Nuraini I. 2006. Manajemen Agribisnis. Jakarta (ID) Universitas Terbuka

Umar H. 2003. Studi Kelayakan Bisnis dalam Bisnis Jasa. Jakarta (ID) : PT Gramedia Pustaka Utama 
Analisis Perbandingan Keuntungan Usaha Pembenihan dan Pendederan Ikan Patin (Pangasius sp.) dengan Perolehan Bunga Deposito Bank

Umar H. 2009. Studi kelayakan Bisnis.

Jakarta (ID): PT. Gramedia

Pustaka Utama

Simorangkir OP. 1986. Dasar-dasar dan

Mekanisme Perbankan. Jakarta

(ID) Aksara Persada Indonesia

Undang-undang RI No. 10 Tahun 1998,

Tentang Perbankan, Jakarta

Sekretariat Kabinet RI

Suyatno Th. 1998. Kelembagaan

Perbankan. Jakarta (ID) Gramedia 
Lampiran 1. Bagan Alir Produksi Benih

\section{Pengelolaan Induk}

- Jumlah, ukuran, dan proporsi indukan yang dipelihara

- Pemberian pakan buatan dengan protein 30-35\%.

- Pengelolaan kualitas media pemeliharaan

- Pengecekan induk ikan yang sakit atau terinfeksi

\section{Seleksi Induk}

- Minimalkan penyebab Stress indukan dan induk yang diseleksi.

- Isolasi dan pemberokan 1-2 malam<smiles>C1CC2CCC1C2</smiles>

\section{Pemijahan}

- Penyuntikan hormon ovaprim

- Stripping

- Pemijahan buatan

\section{Penetasan Telur}

- Penetasan di atas hapa dalam bak larva/ Penetasan dengan corong - Kepadatan \& Hatching rate

\section{Pemeliharaan Larva \& Benih}

- Pemberian pakan alami (Naupli artemia, Cacing sutera/Tubifex dari umur 2 -15 hari.

- Pemberian pakan buatan untuk benih berumur $>15$ hari

- Pengelolaan media pemeliharaan (penyiponan kotoran_aerasi, sirkulasi air panas.)

- Perawatan larva dan benih

- Padat penebaran dan Sintasan

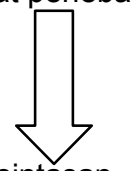

- Padat penebaran dan sintasan
Panen dan Penangana
- Pemberokan dan pemanenan
- Penghitungan
- Packing dan pengangkutan

- Persiapan dan pengelolaan air

Pendederan di kolam

- Pemberian pakan buatan

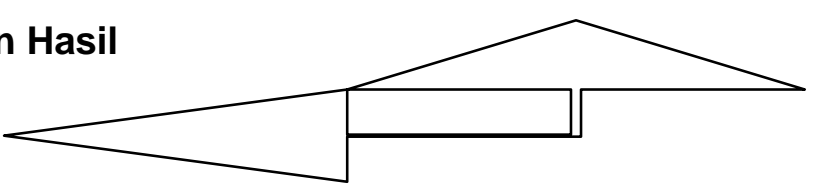

